\title{
„EDUKACJA DLA ROZWOJU - EDUKACJA W ROZWOJU: TEORIA I PRAKTYKA. Zespół Programowy 3. Edukacja na Pograniczach - dokonania i perspektywy". Cieszyn, 24-25 maja 2018 roku
}

W dniach 24-25 maja 2018 roku w Cieszynie odbyła się Ogólnopolska Konferencja Naukowa na temat: EDUKACJA DLA ROZWOJU - EDUKACJA W ROZWOJU: TEORIA I PRAKTYKA. UDANE PRZEDSIĘWZIĘCIA WAŻNE PERSPEKTYWY. Konferencja była uroczystym wydarzeniem w naukowym życiu Wydziału Etnologii i Nauk o Edukacji w Cieszynie wpisującym się w jubileusz 50-lecia Uniwersytetu Śląskiego w Katowicach.

Pracownicy Zakładu Pedagogiki Ogólnej i Metodologii Badań oraz Zakładu Pedagogiki Społecznej i Edukacji Międzykulturowej Wydziału Etnologii i Nauk o Edukacji Uniwersytetu Śląskiego w Katowicach w dniu 25.05.2018 roku byli organizatorami spotkania naukowego, podczas którego głównym obszarem dyskusji uczyniono temat Edukacji na Pograniczach - dokonania i perspektywy.

Współorganizatorami spotkania naukowego były następujące ośrodki naukowe: Katedra Edukacji Międzykulturowej Wydziału Pedagogiki i Psychologii Uniwersytetu w Białymstoku, Instytut Nauk Pedagogicznych Wydział Nauk Społecznych Uniwersytet Opolski, Katedra Socjologii Edukacji i Pedagogiki Społecznej Wydział Nauk Pedagogicznych Uniwersytet Mikołaja Kopernika w Toruniu, Zakład Edukacji Międzykulturowej Wydziału Pedagogiki i Psychologii Uniwersytetu Marii Curie-Skłodowskiej w Lublinie, Zakład Edukacji Międzykulturowej i Badań nad Wsparciem Społecznym Instytut Pedagogiki Wydział Nauk Historycznych i Pedagogicznych Uniwersytet Wrocławski, Wydział Pedagogiczny Uniwersytetu im. Borysa Griczenki w Kijowie, Ukraina Wydział Pedagogiczny Państwowego Uniwersytetu im. Iwana Franki w Żytomierzu, Ukraina oraz Stowarzyszenie Wspierania Edukacji Międzykulturowej.

Koordynatorami Zespołu Programowego były prof. dr hab. Ewa Ogrodzka-Mazur oraz prof. dr hab. Alina Szczurek-Boruta, funkcję sekretarzy objęły dr Urszula Klajmon-Lech oraz dr Katarzyna Jas. 
W dniu 25.05.2018 roku miały miejsce obrady plenarne oraz obrady w sekcjach. Moderatorami obrad plenarnych byli dr hab. Mirosław Sobecki, prof. UwB, dr hab. Krystyna Błeszyńska, prof. SGGW. Swoje wystąpienia zaprezentowali prof. dr hab. Петро Юрійович Cayx, dr hab. Piotr Petrykowski, prof. UMK, dr hab. Krystyna Błeszyńska, prof. SGGW, prof. zw. dr hab. Halina Rusek, dr hab. Paweł Rudnicki, prof. DSW.

Profesor Piotr Petrykowski twierdził, że poszukiwanie „nowych wzorów zachowań" jest przejawem procesów deaksjologizacji.

Przedmiotem wystąpienia dr hab. Krystyny Błeszyńskiej, prof. SGGW były nowe pogranicza kulturowe oraz wiążące się z nimi wyzwania i dylematy edukacyjne. Profesor Krystyna Błeszyńska podkreśliła, że istotnym aspektem procesów globalnych jest wyłanianie się i wzrost znaczenia nowego rodzaju pograniczy kulturowych, do których należą przede wszystkim cyberprzestrzeń oraz przestrzenie globalnego miasta.

Prof. zw. dr hab. Halina Rusek przedstawiła w swoim wystąpieniu nowe podejścia teoretyczne i metodologiczne do wielokierunkowych badań pograniczy. Podkreśliła, że pracownicy Wydziału Etnologii i Nauk o Edukacji w Cieszynie Uniwersytetu Śląskiego w Katowicach od 30 lat prowadzą badania pogranicza polsko-czeskiego. Poczynania te zaowocowały powstaniem subdyscyplin - pedagogicznej oraz antropologii pogranicza.

W referacie pt.: Małe niepubliczne szkoty prowadzone przez organizacje pozarzadowe jako miejsca pracy i animacji społeczności lokalnych. Między afirmacja a anihilacja dr hab. Paweł Rudnicki, prof. DSW zaprezentował wyniki badań realizowanych w pięciu niepublicznych szkołach podstawowych prowadzonych przez organizacje pozarządowe na Dolnym Śląsku. Przedmiotem badania była perspektywa zawodowa nauczycieli i nauczycielek pracujących w placówkach objętych badaniem.

Po sesji planarnej obrady oraz dyskusję kontynuowano w 4 sekcjach.

W sekcji pierwszej Szkoła - doświadczenia i propozycje działań edukacyjnych moderatorami były dr hab. Barbara Grabowska, prof. UŚ oraz dr hab. Anna Szafrańska, prof. UŚ. Wykłady wprowadzające przedstawiły prof. dr hab. Ірина Василівна Саyx, dr hab. Agata Cudowska, prof. UwB oraz dr hab. Marta Urlińska, prof. UMK.

W swoim wystąpieniu dr hab. Agata Cudowska, prof. UwB przedstawiła rozważania dotyczące znaczenia kultury organizacyjnej szkoły w kształtowaniu wspólnoty ludzi uczących się.

Dr hab. Marta Urlińska, prof. UMK, podjęła rozważania na temat animacji współpracy środowiskowej, określiła podmioty uwikłane we współpracę 
w szkole mniejszościowej, stającej się centrum aktywizacji i mobilizacji sił społecznych tkwiących w środowisku lokalnym.

Moderatorami sekcji drugiej podejmującej zagadnienie młodzieży akademickiej wobec problemów $i$ wyzwań wspótczesności były prof. dr hab. Alina Szczurek-Boruta oraz dr hab. Jolanta Suchodolska. Do dyskusji uczestników wprowadziło wystąpienie dr hab. Ewy Skrzetuskiej, prof. SGGW, która przedstawiła opinie studentów pedagogiki na temat szkoły przyszłości.

Doktor Tomasz Bajkowski przedstawił badania dotyczące tożsamości rodziny białostockiej młodzieży akademickiej. W swoich rozważaniach przyjął, że rodzina to pewny azymut poczucia bycia Kimś przynależącym do ważnej, konkretnej wspólnoty rodzinnej.

Miejsce społeczności lokalnych w edukacji i wychowaniu międzykulturowym to temat przewodni sekcji trzeciej, której moderatorami były prof. dr hab. Ewa Ogrodzka-Mazur oraz dr hab. Aniela Różańska. Wykłady wprowadzające wygłosili prof. zw. dr hab. Zenon Jasiński, dr hab. Jolanta Muszyńska, prof. UwB, dr hab. Edward Nycz, prof. UO.

Prof. zw. dr hab. Zenon Jasiński przedstawił założenia pracy wychowawczej w Ochotniczych Hufcach Pracy.

W swoim wystąpieniu dr hab. Jolanta Muszyńska, prof. UwB przedstawiła Pogranicze jako miejsce ambiwalentne, ponieważ w przeświadczeniu określonych grup kulturowych składa się również z „nie-miejsc”.

Profesor Edward Nycz w swoim referacie nakreślił funkcjonowanie gminy miejsko-wiejskiej w świadomości mieszkańców, jednocześnie wskazał na lokalne kapitały mogące stanowić oparcie dla grupy animatorów uczestniczących w projekcie społeczno-kulturalnym mającym zaktywizować społeczność lokalną.

Tematyka sekcji czwartej poświęcona była zagadnieniu kształtowania (się) kompetencji międzykulturowych $w$ środowiskach zróżnicowanych kulturowo. Jako pierwszy głos zabrał prof. dr hab. Hristo Kyuchukov, przedstawiając sytuację dzieci romskich w odniesieniu do koncepcji pedagogicznej Janusza Korczaka.

Kompetencje międzykulturowe polskich emigrantów zarobkowych w Anglii przedstawił na podstawie przeprowadzonych badań dr hab. Mariusz Korczyński, prof. UMCS. Analiza uzyskanych wyników badań wykazała, że badani Polacy, jak i ich pracodawcy uznali analizowane wszystkie kompetencje za ważne dla funkcjonowania zawodowego pracowników. Niestety odmienna sytuacja przedstawia się w zakresie poziomu ich przyswojenia.

Hybrydalne artefakty w kulturze w perspektywie zachowania ciągłości w kulturze i kształtowania kompetencji do komunikacji międzykulturowej 
przedstawiła w swoim wystąpieniu dr hab. Dorota Misiejuk, prof. UwB. Konferencji towarzyszyła również sesja posterowa.

Ważnym wydarzeniem podczas konferencji było Walne Zebranie Członków istniejącego od października 2008 roku Stowarzyszenia Wspierania Edukacji Międzykulturowej (SWEM). Stowarzyszenie liczy 60 członków, Zarząd SWEM tworzą: przewodnicząca - dr hab. Dorota Misiejuk, prof. UwB, zastępca przewodniczącej - dr hab. Barbara Grabowska, prof. UŚ, skarbnik - dr hab. Anna Szafrańska, prof. UŚ i sekretarz - dr hab. prof. UwB Jolanta Muszyńska. Na zebraniu Zarząd przedstawił sprawozdanie finansowe i merytoryczne za rok 2017. Podczas zebrania dyskutowano również na temat kierunków dalszego rozwoju i form działalności. Członkowie Stowarzyszenia podjęli decyzję o utworzeniu strony internetowej.

W obradach Zespołu Programowego 3 wzięły udział 52 osoby, w tym dwoje gości zagranicznych. Uczestnikami konferencji byli przedstawiciele różnych ośrodków akademickich w Polsce i za granicą reprezentujący: Uniwersytet Mikołaja Kopernika w Toruniu, Szkołę Główną Gospodarstwa Wiejskiego w Warszawie, Uniwersytet Śląski w Katowicach, Dolnośląską Szkołę Wyższą we Wrocławiu, Uniwersytet w Białymstoku, Uniwersytet Marii Curie-Skłodowskiej w Lublinie, Uniwersytet Łódzki, Akademię Ignatianum w Krakowie, Wyższą Szkołę Społeczno-Przyrodniczą im. W. Pola w Lublinie, Uniwersytet Opolski, Uniwersytet Wrocławski, Akademię Humanistyczną im. A. Gieysztora w Pułtusku, Uniwersytet im. Borysa Griczenki w Kijowie, Uniwersytet im. Iwana Franki w Żytomierzu.

Spotkanie naukowe nt. „Edukacji na Pograniczach - dokonania i perspektywy" stało się okazją do naukowej refleksji związanej z pograniczem, jego wartością dla edukacji, socjalizacją, kształtowaniem się tożsamości oraz uwarunkowaniami społecznymi, kulturowymi i politycznymi. 